RAD Conference Proceedings, vol. 4, pp. 11-17, 2020

ISSN 2466-4626 (online) | DOI: 10.21175/RadProc.2020.03

www.rad-proceedings.org

\title{
MAGNESIUM POTASSIUM PHOSPHATE MATRIX FOR THE IMMOBILIZATION OF RADIOACTIVE WASTE GENERATED DURING THE REPROCESSING OF MIXED URANIUM PLUTONIUM NITRIDE SPENT NUCLEAR FUEL
}

\author{
S.E. Vinokurov*, S.A. Kulikova
}

Vernadsky Institute of Geochemistry and Analytical Chemistry, Russian Academy of Sciences, Moscow, Russia

\begin{abstract}
This article summarizes the results of our research on the possibility of using a magnesium potassium phosphate (MPP) matrix to solve the problem of immobilization of radioactive waste ( $R W$ ) generated during reprocessing of mixed uranium plutonium nitride spent nuclear fuel. We used $\mathrm{CaCO}_{3}$ as a surrogate of waste containing ${ }^{14} \mathrm{C}$, as well as an aqueous solution of $41.6 \% \mathrm{LiCl}-52.9 \% \mathrm{KCl}-5.5 \% \mathrm{CsCl}$ as a surrogate of the spent electrolyte formed during the pyrochemical fuel reprocessing. The mechanical, radiation and hydrolytic stability of the obtained compounds were investigated. It was found that the compounds have a high compressive strength of 17$26 \mathrm{MPa}$. The minimum carryover of carbon dioxide into the atmosphere during the synthesis and keeping of the samples for 14 days was noted - no more than 3 wt\%. It was found that the change of the matrix phase occurs during the irradiation by accelerated electrons during the accumulation of the absorbed dose of $10^{8} \mathrm{~Gy}$. In this case, the leaching rate of components of the compound including irradiated one corresponds to the current regulatory requirements for materials for $R W$ immobilization. The differential leaching rate of $C s$ at $25{ }^{\circ} \mathrm{C}$ from monolithic samples containing $\mathrm{LiCl}-\mathrm{KCl}-\mathrm{CsCl}$ on the $91^{\text {st }}$ day of samples contact with water was $\left(5^{-11}\right) \times 10^{-5} \mathrm{~g} /\left(\mathrm{cm}^{2} \cdot \mathrm{day}\right)$ (according to GOST R 52126-2003 test), and was $(4-29) \times 10^{-7} \mathrm{~g} /\left(\mathrm{cm}^{2} \cdot\right.$ day) on the $7^{\text {th }}$ day at $90^{\circ} \mathrm{C}$ from crushed samples (in accordance with PCT standard). The thermal stability of the compound containing LiCl-KCl-CsCl up to $450^{\circ} \mathrm{C}$ was shown.
\end{abstract}

Key words: Carbon-14, cesium, hydrolytic stability, immobilization, magnesium potassium phosphate matrix, mixed nitride uranium plutonium fuel, radiation resistance, radioactive waste, spent electrolyte, spent nuclear fuel

\section{INTRODUCTION}

Nowadays, Russia is focused on the closure of the nuclear fuel cycle. New types of fast neutron reactors and new types of nuclear fuel, including reprocessing methods of spent nuclear fuel (SNF), are being developed [1]. Combined pyrochemical and hydrometallurgical technology (so-called "PHprocess") was proposed for the reprocessing of mixed nitride uranium plutonium (MNUP) SNF of leadcooled BREST-OD-300 reactor [2].

In the hydrometallurgical reprocessing of MNUP SNF from the BREST-OD-300 reactor, almost all ${ }^{14} \mathrm{C}$ formed as a result of the neutron capture reaction is released into the gas phase in the form of carbon dioxide during the operation of fuel oxidation (volume oxidation) and its separation from the cladding of fuel elements. The resulting carbon dioxide containing ${ }^{14} \mathrm{C}$ is sent to the absorption column, which is irrigated with an aqueous solution of sodium hydroxide in a circulation mode [3]. Calcium hydroxide, which concentrates ${ }^{14} \mathrm{C}$ in the form of calcium carbonate, is used to regenerate the sodium hydroxide solution $[4,5]$.

In the pyrochemical reprocessing of MNUP SNF, its anodic dissolution in the melt of alkali metal chlorides and the cathodic deposition of fissile materials are carried out using a liquid cadmium cathode [2].
Various systems are proposed as electrolytes, including $\mathrm{LiCl}-\mathrm{KCl}-\mathrm{CsCl}$, as well as $\mathrm{NaCl}-2 \mathrm{CsCl}, \mathrm{NaCl}-\mathrm{KCl}$, $\mathrm{LiCl}-4.53 \mathrm{NaCl}-4.88 \mathrm{KCl}-0.66 \mathrm{CsCl}, 3 \mathrm{LiCl}-2 \mathrm{KCl}$ and others [6].

Waste containing ${ }^{14} \mathrm{C}$ and spent electrolyte are radioactive waste (RW), so they need to be converted into stable form. Glass is the only matrix for solidification of high level RW (HLW) used in Russia, Great Britain, Germany, France, USA, China and other countries [1]. However, vitrification technology is not suitable for immobilization of volatile radionuclides, since the process proceeds at a high temperature (for phosphate glass at $900-1050^{\circ} \mathrm{C}[7]$, and borosilicate glass at about $1150^{\circ} \mathrm{C}$ [8]), which may lead to volatilization both radiocarbon (during the decomposition of $\mathrm{CaCO}_{3}$ ) and cesium isotopes at temperatures above $750^{\circ} \mathrm{C}[9,10]$.

For this reason, a magnesium potassium phosphate (MPP) matrix based on $\mathrm{MgKPO}_{4} \times 6 \mathrm{H}_{2} \mathrm{O}$ [11] obtained at room temperature according to the reaction (1) is of special interest for the immobilization of such RW.

$$
\mathrm{MgO}+\mathrm{KH}_{2} \mathrm{PO}_{4}+5 \mathrm{H}_{2} \mathrm{O} \rightarrow \mathrm{MgKPO}_{4} \times 6 \mathrm{H}_{2} \mathrm{O}
$$

The MPP matrix is an effective mineral-like material that minimizes the yield of highly toxic radionuclides, which makes it suitable for RW immobilization of different activity levels [12-19].

*vinokurov.geokhi@gmail.com 
S. Vinokurov et al., Magnesium potassium phosphate matrix..., RAD Conf. Proc., vol. 4, 2020, 11-17

The purpose of our research was approbation the MPP matrix for immobilization of RW surrogates containing radiocarbon ${ }^{14} \mathrm{C}$ in the form of calcium carbonate and spent electrolyte in the $\mathrm{LiCl}-\mathrm{KCl}-\mathrm{CsCl}$ system, including the determination of the physical and chemical characteristics and hydrolytic stability of the resulting compounds.

\section{MATERIALS AND METHODS}

The experiments were carried out in a glove box (Pererabotka, Dzerzhinsk, Nizhny Novgorod region, Russia) at ambient atmospheric conditions. All chemicals were no less than chemically pure grade.

\subsection{Preparation of the MPP compound samples}

Synthesis of the MPP matrix was carried out in accordance with the procedure described earlier in our article [14] at the MgO: $\mathrm{H}_{2} \mathrm{O}: \mathrm{KH}_{2} \mathrm{PO}_{4}$ weight ratio of 1: $2: 3$ (molar ratio of 1.1: $5: 1$ ). We used MgO (Rushim LLC, Moscow, Russia) precalcined at $1300^{\circ} \mathrm{C}$ for $3 \mathrm{~h}$ (specific surface area was $6.6 \mathrm{~m}^{2} / \mathrm{g}$ ) and $\mathrm{KH}_{2} \mathrm{PO}_{4}$ (Chimmed LLC, Moscow, Russia) crushed to a particle size of $0.15^{-0.25} \mathrm{~mm}$.

Compounds containing up to 50 wt $\% \mathrm{CaCO}_{3}$ were prepared by consistent mixing of the matrix components $\left(\mathrm{H}_{2} \mathrm{O}, \mathrm{KH}_{2} \mathrm{PO}_{4}, \mathrm{MgO}\right)$ and adding $\mathrm{CaCO}_{3}$ at the final stage to minimize the carryover of carbon dioxide into the atmosphere during the synthesis of the MPP compound. Determination of gas evolution during the addition of reagents, stirring, setting and subsequent solidification of MPP compounds containing $\mathrm{CaCO}_{3}$ was carried out using a sealed installation, the scheme of which is given in [4]. The content of carbon dioxide within the installation volume was determined with a Master KIT MT 8057S detector.

In addition, samples were prepared by solidification of aqueous solution of $\mathrm{LiCl}-\mathrm{KCl}-\mathrm{CsCl}$ with a ratio of $41.6 \%-52.9 \%-5.5 \%$ (as a surrogate of spent electrolyte, according to [20]). Compounds containing up to 20 wt\% $\mathrm{LiCl}-\mathrm{KCl}-\mathrm{CsCl}$, including those containing 28.6 wt\% zeolite (hereinafter the samples are named MPPZ) were also prepared [1]. The natural zeolite of the Sokyrnytsya deposit, Transcarpathian region (ZEO-MAX LLC, Ramenskoye, Moscow region, Russia) with a particle size of $0.07-0.16 \mathrm{~mm}$ and a specific surface area of $17.5 \mathrm{~m}^{2} / \mathrm{g}$ was used for preliminary cesium binding and for increasing the mechanical strength of the MPP compound [21].

To study the hydrolytic stability of the compound, samples were also prepared by solidification of

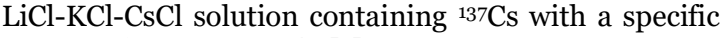
activity of $1.0 \times 10^{7} \mathrm{~Bq} / \mathrm{L}[1]$.

Cubic samples of the MPP compound with dimensions of $2 \times 2 \times 2 \mathrm{~cm}$ were prepared. The samples were kept in air for 15 days to cure.

\subsection{Investigation of the obtained MPP compound samples}

The phase composition of the obtained MPP compound samples was identified by the X-ray diffraction (XRD) method (Ultima-IV, Rigaku, Tokyo,
Japan). The XRD data were interpreted using the Jade 6.5 program package (MDI, Livermore, CA, USA) with PDF-2 powder database.

The compressive strength of the MPP compounds was determined using a test machine Cybertronic $500 / 50 \mathrm{kN}$ (Testing Bluhm \& Feuerherdt $\mathrm{GmbH}$, Germany) and a laboratory test press PRG-1-50 (VNIR, Moscow, Russia).

The MPP compounds containing $\mathrm{CaCO}_{3}$ were irradiated using an ILU-6 pulsed linear electron accelerator with energies up to $2.5 \mathrm{MeV}$. The exposure time to achieve the set doses was determined by calibrating of film dosimeters $\mathrm{SO} \mathrm{PD}(\mathrm{F}) \mathrm{R}-5 / 5 \mathrm{O}$ (GSO 7865-2000) located at different distances from the center of the beam. The absorbed dose rate was $(1.1-2.5) \times 10^{3} \mathrm{~Gy} / \mathrm{s}$, depending on the location of the sample on the accelerator from the center of the electron beam. The absorbed dose was calculated from the absorption spectra at a wavelength of $513 \mathrm{~nm}$ of the irradiated dosimeter film obtained using an SF-56 scanning spectrophotometer. Unirradiated film samples were used as a reference sample.

Thermal stability of the MPP compounds obtained after solidification the LiCl-KCl-CsCl solution up to temperature $450^{\circ} \mathrm{C}$ was investigated in accordance with the current requirements for solidified HLW [22]. For this purpose, the samples were kept at $180^{\circ} \mathrm{C}$ for $10 \mathrm{~h}$ (to remove bound water) and at $450^{\circ} \mathrm{C}$ for $4 \mathrm{~h}$ (hereinafter named MPPZ_180 and MPPZ_450, respectively) in a muffle furnace (SNOL 30/1300, AB UMEGA GROUP, Utena, Lithuania).

The hydrolytic stability of the MPP compounds was determined in accordance with the semi-dynamic standard GOST R 52126-2003 at $25 \pm 3{ }^{\circ} \mathrm{C}$ [23] and the static standard PCT (Method A) at $90 \pm 2{ }^{\circ} \mathrm{C}$ [24]. In accordance with GOST R 52126-2003, before leaching monolithic cubic samples (open geometric surface area about $24 \mathrm{~cm}^{2}$ ) of the compound were immersed in ethanol for $5^{-7} \mathrm{~s}$ to clean them from mechanical impurities, then the samples were dried in air for 30 min. Bidistilled water (pH $6.6 \pm 0.1$, volume $200 \mathrm{~mL}$ ) was used as a leaching agent with its periodic replacement after 1, 3, 7, 10, 14, 21 days, the total test duration was 28 days, and in the case of the compound containing $\mathrm{LiCl}-\mathrm{KCl}-\mathrm{CsCl}$ was 90-91 days. PCT leaching test was carried out on $0.07-0.16 \mathrm{~mm}$ powders that were obtained by crushing and sieving the samples (surface of the crushed samples determined by the BET method was 15.9; 9.5 and 6.4 for MPPZ; MPPZ_180 and MPPZ_450 compound samples respectively [1]). Compound powders were washed by bidistilled water and ethanol. Conditions PCT: test duration -7 days $\pm 2 \%$, leaching agent bidistilled water $(\mathrm{pH} 6.6 \pm 0.1)$, leachate volume/sample weight $-10 \pm 0.5 \mathrm{~mL} / \mathrm{g}$. Fluoroplastic containers with tightly closed lids, as well as an electric drying oven 2V-151 (Medlabortekhnika, Odessa, Ukraine) to maintain the temperature were used in the experiments. The solutions after leaching were decanted and the content of compound components in them was determined by ICP-AES and ICP-MS (iCAP6500 Duo and $\mathrm{X}$ Series2 respectively, Thermo

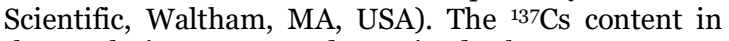
the solutions was determined by gamma-ray spectrometry on a spectrometer Alpha Analyst with a 
S. Vinokurov et al., Magnesium potassium phosphate matrix..., RAD Conf. Proc., vol. 4, 2020, 11-17

high-purity germanium detector GC 1020 (Canberra Ind, Meriden, CT, USA). The content of potassium, magnesium, calcium and phosphorus (in terms of phosphate ion) in solutions was determined by atomic emission spectrometry using an equipment including STE-1 spectrometers with a photodiode array MAES no. M10052 and PGS-2 with a photodiode array MAES no. Mo8077 with Atom-3.3 software and a Vesuvius-3 generator. The content of carbonate ion in solutions after leaching was determined using a carbonate selective electrode $\mathrm{XC}-\mathrm{CO}_{3}-\mathrm{OO} 1$.

\section{RESULTS AND DISCUSSION}

\subsection{Immobilization of calcium carbonate as ${ }^{14} \mathrm{C}$ waste surrogate}

During the studying of the phase composition of samples containing $\mathrm{CaCO}_{3}$, it was shown that all the obtained compounds consist of the phases $\mathrm{MgKPO}_{4} \times 6 \mathrm{H}_{2} \mathrm{O}, \mathrm{MgO}$, and $\mathrm{CaCO}_{3}$, including after irradiation to a dose of $10^{6} \mathrm{~Gy}$ (the requirement for cement compound for the RW immobilization in Russia [22]) and even up to $10^{7} \mathrm{~Gy}$. An example of a diffractogram is shown in Figure 1. At the same time, with an increase in the irradiation dose of compounds containing $40 \mathrm{wt} \% \mathrm{CaCO}_{3}$ to a dose of $10^{8} \mathrm{~Gy}$, the diffraction reflections of the $\mathrm{MgKPO}_{4} \times 6 \mathrm{H}_{2} \mathrm{O}$ phase were not identified. It was found that the irradiated samples are composed of the phases of trigonal $\mathrm{CaCO}_{3}$, cubic $\mathrm{MgO}$, monoclinic magnesium pyrophosphate $\mathrm{Mg}_{2} \mathrm{P}_{2} \mathrm{O}_{7}$, and the minor phase $\mathrm{K}_{6} \mathrm{P}_{6} \mathrm{O}_{18} \times 3 \mathrm{H}_{2} \mathrm{O}$. Such a change in the phase composition is probably associated with the destruction of the target phase during radiation and thermal exposure under the action of accelerated electrons. Obviously, as a result of this effect, the decomposition of crystalline hydrate $\mathrm{MgKPO}_{4} \times 6 \mathrm{H}_{2} \mathrm{O}$ occurred with the removal of bound water, and, probably, the decomposition of this phase into simpler and thermodynamically more stable crystalline phosphate structures due to crystallization of new phases could occur [5].

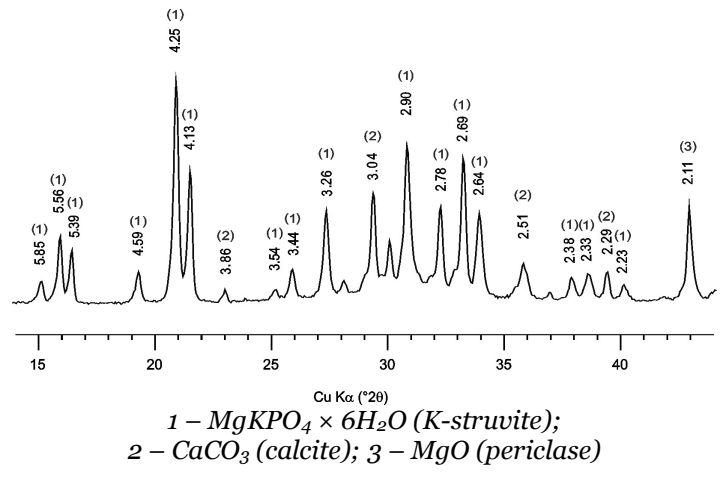

Figure 1. X-ray diffraction pattern of MPP compound containing 10 wt $\% \mathrm{CaCO}_{3}$

During the study of the mechanical strength of the samples obtained, it was found that their compressive strength is $22 \pm 5 \mathrm{MPa}$ (Figure 2) [4], which meets the requirements for a cement compound (not less than
4.9 MPa) [22]. It should be noted that the strength of the compounds during immobilization of calcium carbonate does not decrease relative to the strength of the blank sample of the MPP matrix [13].

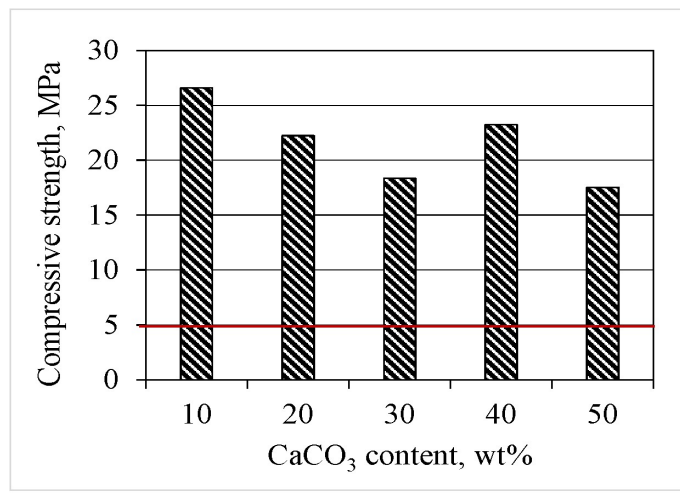

Figure 2. Compressive strength of the MPP compounds containing $\mathrm{CaCO}_{3}$ [4]

The $\mathrm{CO}_{2}$ content released from the MPP compounds containing $\mathrm{CaCO}_{3}$ during synthesis and curing of samples was periodically determined in the air atmosphere of the sealed box. Figure 3 shows a dependence of the amount of evolved gas for the sample of MPP compound containing 20 wt\% $\mathrm{CaCO}_{3}$. As a result, it was found that in all experiments already after 7-8 days of keeping the compound, the level of released $\mathrm{CO}_{2}$ became constant and did not change until the end of keeping (14 days), and its percentage did not exceed $2-3 \%$ of initial carbonate added in the compound [4].

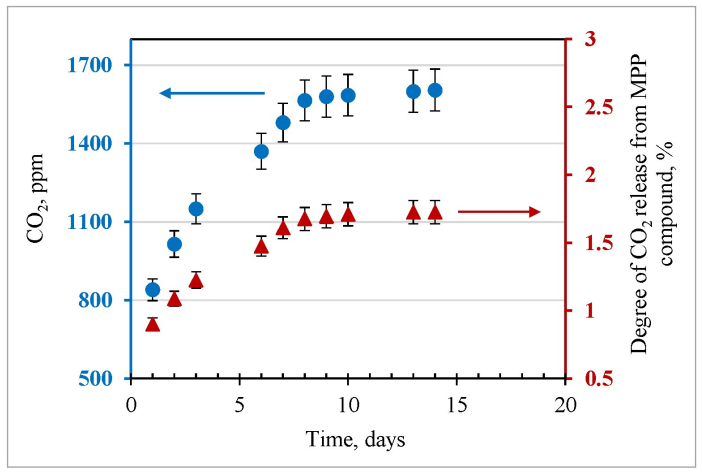

Figure 3. Dependence of the amount of evolved $\mathrm{CO}_{2}$ during curing of MPP compound containing $20 \mathrm{wt} \% \mathrm{CaCO}_{3}$ [4]

During study of hydrolytic stability of the MPP compound samples in accordance with GOST R 521262003 test, it was established that the kinetic curves of the leaching rate of compound components have a similar nature for the samples studied containing 20 or 40 wt\% $\mathrm{CaCO}_{3}$, including ones after the accumulation of a dose of $10^{8} \mathrm{~Gy}$. The data on leaching rate in the case of the sample containing 40 wt\% $\mathrm{CaCO}_{3}$ is presented in Figure 4, as well as in the Table 1 [5].

Data in Figure 4 shows that during the test the leaching rate of components decreases, that is explained by the main kinetic stage of matrix corrosion 
S. Vinokurov et al., Magnesium potassium phosphate matrix..., RAD Conf. Proc., vol. 4, 2020, 11-17

- the initial leaching rate. The relatively high values of the leaching rates are explained by the mechanism of ion exchange and diffusion of the contact solution due to the compensation of the matrix surface charge by water molecules, and, further, by hydrolysis of the matrix components. In general, it can be noted that the leaching rates are at an acceptable level and slightly exceed it for single components of the compound. It should be noted that the leaching rate of the components does not significantly depend on the absorbed dose (Table 1) [5].

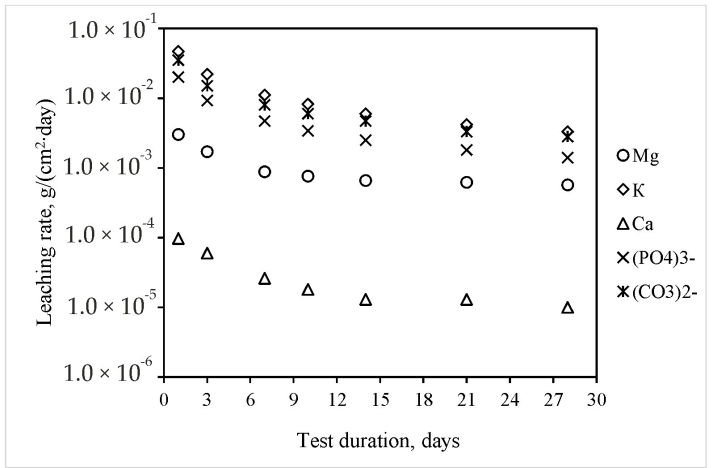

Figure 4. Hydrolytic stability of MPP compound containing $40 \mathrm{wt} \% \mathrm{CaCO}_{3}[5]$

Table 1. Hydrolytic stability of MPP compound samples containing $40 \mathrm{wt} \% \mathrm{CaCO}_{3}$, irradiated by accelerated electrons, on the $28^{\text {th }}$ day of contact with water [5]

\begin{tabular}{|c|c|c|c|c|c|}
\hline \multirow{2}{*}{$\begin{array}{c}\text { Absorbed } \\
\text { dose, Gy }\end{array}$} & \multicolumn{5}{|c|}{$\begin{array}{c}\text { ceaching rate of the compound } \\
\text { components, } \mathrm{g} /\left(\mathrm{cm}^{2} \text {.day }\right.\end{array}$} \\
\cline { 2 - 6 } & $\mathrm{K}$ & $\mathrm{Mg}$ & $\mathrm{Ca}$ & $\left(\mathrm{PO}_{4}\right)^{3}$ & $\left(\mathrm{CO}_{3}\right)^{2-}$ \\
\cline { 2 - 6 } & $10^{3}$ & $10^{4}$ & $10^{5}$ & $10^{3}$ & $10^{3}$ \\
\hline $\mathrm{O}$ & 3.3 & 5.7 & 1.0 & 1.4 & 2.8 \\
$10^{8}$ & 3.3 & 5.9 & 1.9 & 0.5 & 4.3 \\
\hline
\end{tabular}

The obtained research results make it possible to estimate the storage time of the MPP compound containing waste with ${ }^{14} \mathrm{C}$. As an example, take the sample with a loading of 20 wt\% $\mathrm{CaCO}_{3}$. During SNF reprocessing, according to the calculation data, $1.28 \mathrm{~kg}$ of ${ }^{14} \mathrm{C}$ per year with a total activity of $6.9 \times 10^{14} \mathrm{~Bq}$ is formed during volume oxidation operations of MNUP SNF. After ${ }^{14} \mathrm{C}$ capturing and its curing, about $682 \mathrm{~kg}$ of $\mathrm{CaCO}_{3}$ are formed from the absorption column and, accordingly, MPP compound weighing $3410 \mathrm{~kg}$ with a $\mathrm{CaCO}_{3}$ content of 20 wt\%. The specific activity of the compound will be $2.02 \times 10^{11} \mathrm{~Bq} / \mathrm{kg}$. It was shown that at a dose of $10^{8} \mathrm{~Gy}$, the material will undergo destruction, i.e. will get an energy of $10^{8} \mathrm{~J} / \mathrm{kg}$. Since $\mathrm{T}_{1 / 2}$ for ${ }^{14 \mathrm{C}}$ is 5730 years, and the energy of one $\beta^{-}$-decay of ${ }^{14} \mathrm{C}$ is $156.47 \mathrm{keV}$, then for the compound with 20 wt\% $\mathrm{CaCO}_{3}$ content will accumulate a dose of $10^{8} \mathrm{~Gy}$ for 2300 years. It should be emphasized that this can be true only during the condition that all the energy released at the $\beta^{-}$-decay of ${ }^{14} \mathrm{C}$ will be absorbed by the matrix [5]. It is also important to take into account that in practice, the filling of the compound by waste will be much lower. So, when filling by waste of the compound is about $5 \mathrm{wt} \%$, it is possible to rely on the stability of the matrix for at least about nine thousand years during which the activity of waste will significantly decrease.

\subsection{Immobilization of $\mathrm{LiCl}-\mathrm{KCl}-\mathrm{CsCl}$ as surrogate spent electrolyte}

It was established that MPP compound successfully form in surrogate solution of spent electrolyte $\mathrm{LiCl}-\mathrm{KCl}-\mathrm{CsCl}$; the obtained $\mathrm{X}$-ray diffraction pattern is shown in Figure 5 [1]. It was confirmed that $\mathrm{MgKPO}_{4} \times 6 \mathrm{H}_{2} \mathrm{O}$ an analog of K-struvite [25], which is the main crystalline phase of the studied compound. The salts of $\mathrm{KCl}$ and $\mathrm{LiCl}$ were detected in the compound obtained in the case of solidification of the electrolyte surrogate (Figure 5), and the salt of $\mathrm{CsCl}$ was not found due to its low content in the compound (less than $1 \mathrm{wt} \%$ ) [1].

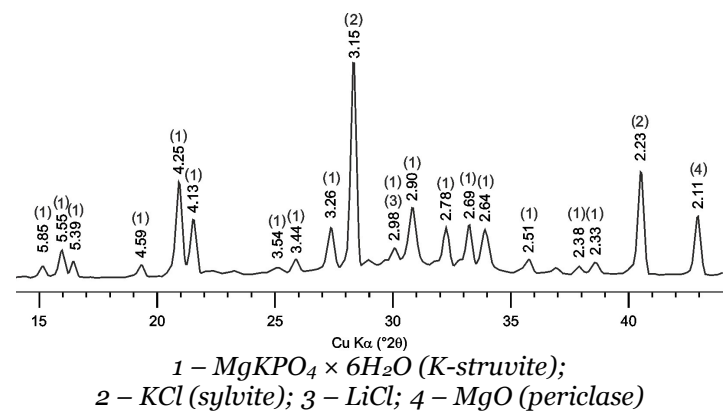

Figure 5. X-ray diffraction pattern of the MPP compound containing $\mathrm{LiCl}-\mathrm{KCl}-\mathrm{CsCl}[1]$

It was found that the compressive strength of compounds containing LiCl-KCl-CsCl solution was 9.1 $\pm 0.4 \mathrm{MPa}$, which corresponded to the requirements [22]. At the same time, it was noted that at heating to $450{ }^{\circ} \mathrm{C}$ of the compound, the samples practically lost their compressive strength. Earlier in our article [21] it was established that the addition of about 29 wt\% zeolite to the composition of the MPP compound led to a significant increase in both mechanical strength and thermal stability of samples. To study the influence of zeolite on the efficiency of immobilization of spent electrolyte, compound samples obtained during solidification of $\mathrm{LiCl}-\mathrm{KCl}-\mathrm{CsCl}$ solution and contained $28.6 \mathrm{wt} \%$ zeolite were used.

The data on the compressive strength of the MPP compound containing $\mathrm{LiCl}-\mathrm{KCl}-\mathrm{CsCl}$ solution and 28.6 wt\% zeolite is shown in Figure 6. It was found that the compressive strength of the compound increases 1.9-2.7 times with the addition of 28.6 wt\% zeolite, obviously due to the filling of pores in the compound volume, as it was shown previously for cement in [26]. The compressive strength of the samples was 17-26 MPa, and after heat treatment at 180 and $450^{\circ} \mathrm{C}$ it was $16-20$ and $9-13 \mathrm{MPa}$ respectively. It was pointed that an increase of the content of $\mathrm{LiCl}-\mathrm{KCl}-\mathrm{CsCl}$ from 10 to $20 \mathrm{wt} \%$ in the compound not only did not reduce the compressive strength of the compound, but on the other hand, there was a tendency to increase it (Figure 6) [1].

During study of hydrolytic stability of the MPPZ compound samples in accordance with GOST R 52126- 
S. Vinokurov et al., Magnesium potassium phosphate matrix..., RAD Conf. Proc., vol. 4, 2020, 11-17

2003 test, it was established that the kinetic curves of the ${ }^{137} \mathrm{Cs}$ leaching rate have a similar nature for the studied samples containing 10 or 20 wt\% $\mathrm{LiCl}-\mathrm{KCl}-\mathrm{CsCl}$, and after their heat treatment. The data on differential leaching rate in the case of the sample with 20 wt\% $\mathrm{LiCl}-\mathrm{KCl}-\mathrm{CsCl}$ is presented in Figure 7.

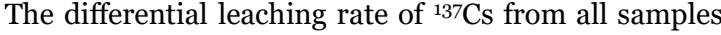
on the $91^{\text {st }}$ day of contact of the samples with water was $\left(5^{-11}\right) \times 10^{-5} \mathrm{~g} /\left(\mathrm{cm}^{2} \cdot\right.$ day $)$. The heat treatment of the compounds at $450{ }^{\circ} \mathrm{C}$ did not lead to a significant change in rate, which was $(7-11) \times 10^{-5} \mathrm{~g} /\left(\mathrm{cm}^{2}\right.$.day $)[1]$.

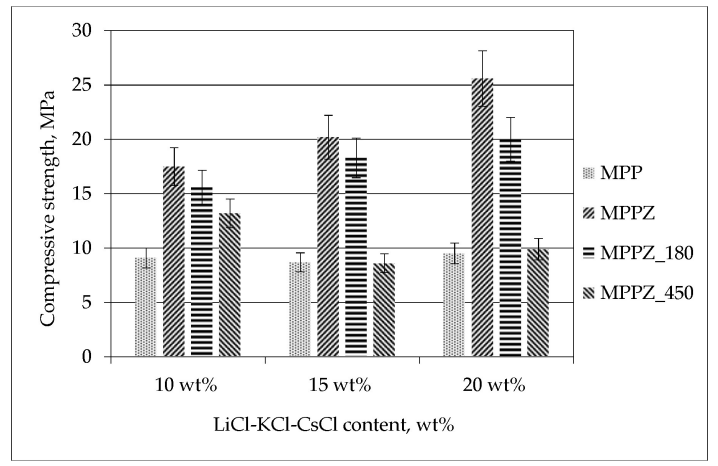

Figure 6. Compressive strength of the MPP compound containing $\mathrm{LiCl}-\mathrm{KCl}-\mathrm{CsCl}$ and $28.6 \mathrm{wt} \%$ zeolite [1]

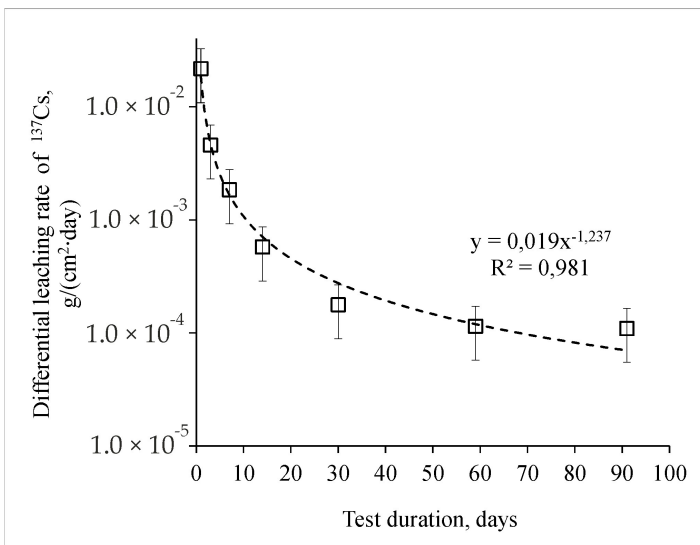

Figure 7. Kinetic curve of the leaching rate of ${ }_{137 \mathrm{Cs}}$ from MPPZ compound containing $20 \mathrm{wt} \% \mathrm{LiCl}-\mathrm{KCl}-\mathrm{CsCl}$ and $28.6 \mathrm{wt} \%$ zeolite in accordance with GOST R 52126-2003 test [1]

The data on leaching rate of compound components in accordance with PCT standard are presented in Table 2 [1]. It was shown that the MPP compounds have high hydrolytic stability also at $90 \pm 2{ }^{\circ} \mathrm{C}$. Leaching rate of $\mathrm{Cs}$ was less than $1.9 \times 10^{-6}$ $\mathrm{g} /\left(\mathrm{cm}^{2}\right.$.day), which corresponded to the leaching rate of Cs from high-temperature matrices with almost the same load of waste. For example, it was shown in [27], that normalized release of $\mathrm{Cs}\left(\mathrm{g} / \mathrm{m}^{2}\right)$ after 7 days leaching test at $90 \pm 2{ }^{\circ} \mathrm{C}$ from samples in the system $\mathrm{SiO}_{2}-\mathrm{Al}_{2} \mathrm{O}_{3}-\mathrm{P}_{2} \mathrm{O}_{5}$, mixed with glass frit or borosilicate glass and containing 23.33 wt\% surrogate of spent electrolyte from pyrochemical reprocessing of SNF, was 0.0395 or $0.811-1.36$, that corresponded to a normalized release rate of $\mathrm{Cs}-5.6 \times 10^{-7}$ or $(1.2-1.9) \times 10^{-5} \mathrm{~g} /\left(\mathrm{cm}^{2} \cdot\right.$ day $)$ respectively [1].

Table 2. Hydrolytic stability of MPP compound samples containing 20 wt\% $\mathrm{LiCl}-\mathrm{KCl}-\mathrm{CsCl}$ and $28.6 \mathrm{wt} \%$ zeolite in accordance with PCT standard [1]

\begin{tabular}{|c|c|c|c|c|c|}
\hline \multirow{3}{*}{ Compound } & \multicolumn{5}{|c|}{$\begin{array}{l}\text { Leaching rate of the compound } \\
\text { components, } \mathrm{g} /\left(\mathrm{cm}^{2} \cdot \text { day }\right)\end{array}$} \\
\hline & $\mathrm{Mg}$ & $\mathrm{P}$ & $\mathrm{K}$ & Cs & $\mathrm{Li}$ \\
\hline & $10^{9}$ & $10^{7}$ & $10^{6}$ & $10^{6}$ & $10^{7}$ \\
\hline MPPZ & 0.8 & 1.6 & 1.6 & 1.9 & 0.3 \\
\hline MPPZ_180 & 1.3 & 2.6 & 2.6 & 2.9 & $3 \cdot 3$ \\
\hline MPPZ_450 & 2.8 & 4.1 & 3.7 & 2.1 & 4.0 \\
\hline
\end{tabular}

\section{CONCLUSION}

The efficiency of applying of the MPP matrix for the immobilization of RW generated during the reprocessing of MNUP SNF were shown. The possibility of immobilization of $\mathrm{CaCO}_{3}$ up to $50 \mathrm{wt} \%$ (as surrogate of RW containing ${ }^{14} \mathrm{C}$ ), as well as of surrogate of spent electrolyte $\mathrm{LiCl}-\mathrm{KCl}-\mathrm{CsCl}$ up to $20 \mathrm{wt} \%$ was shown. The characteristics - compressive strength, thermal stability, hydrolytic stability - of the obtained MPP compound correspond to the current regulatory requirements for materials for the RW immobilization in Russia. It was also established that the absorbed dose up to $10^{8}$ Gy does not lead to a significant change in the hydrolytic stability of the matrix, but the structure of the matrix changes. It is calculated that the compound containing 5 wt\% $\mathrm{CaCO}_{3}$ will retain its structure for at least nine thousand years. The study of the behavior of the compound during radiation exposure requires additional research.

Acknowledgements: This work was supported by the Russian Science Foundation (project 16-13-10539).

\section{REFERENCES}

1. S.A. Kulikova, K.Y. Belova, E.A. Tyupina, S.E. Vinokurov, "Conditioning of spent electrolyte surrogate $\mathrm{LiCl}-\mathrm{KCl}-\mathrm{CsCl}$ using magnesium potassium phosphate Compound," Energies, vol. 13, no. 8, 1963, 2020.

https://doi.org/ 10.3390/en13081963

2. A.Yu. Shadrin, K.N. Dvoeglazov, A.G. Maslennikov, V.A. Kashcheev, S.G. Tret'yakova, O.V. Shmidt, V.L. Vidanov, O.A. Ustinov, V.I. Volk, S.N. Veselov, V.S. Ishunin, "PH process as a technology for reprocessing mixed uranium-plutonium fuel from BREST-OD-300 reactor," Radiochemistry, vol. 58, no. 3, pp. 271-279, 2016.

http://dx.doi.org/10.1134/S1066362216030085

3. S.A. Yakunin, O.A. Ustinov, A.Yu. Shadrin, O.V. Shudegova, "Purification of gaseous emissions by ${ }^{14} \mathrm{C}$ removal during reprocessing of spent uraniumplutonium nuclear fuel," Atomic Energy, vol. 120, no. 3, pp. 229-232. Jul. 2016. http://dx.doi.org/10.1007/s10512-016-0122-y

4. A.V. Dmitrieva, M.Yu. Kalenova, S.A. Kulikova, I.V. Kuznetsov, A.M. Koshcheev, S.E. Vinokurov, "Magnesium-potassium phosphate matrix for immobilization of ${ }^{14 C}$," Russ. J. Appl. Chem., vol. 91, no. 4, pp. 641-646, 2018.

http://dx.doi.org/10.1134/S107042721804016X 
S. Vinokurov et al., Magnesium potassium phosphate matrix..., RAD Conf. Proc., vol. 4, 2020, 11-17

5. A.A. Lizin, D.M. Yandaev, A.Yu. Shadrin, M.Yu. Kalenova, A.V. Dmitrieva, S.V. Tomilin, I.S. Golubenko, M.I. Khamdeev, V.N. Momotov, D.E. Tikhonova, O.S. Dmitrieva, A.A. Kolobova, S.S. Poglyad, M.V. Dodonova, S.E. Vinokurov, B.F. Myasoedov "Radiation and chemical stability of a magnesium-phosphate matrix for ${ }^{14} \mathrm{C}$ immobilization," Radiochemistry, vol. 62, no. 1, pp. 131-137, 2020. http://dx.doi.org/10.1134/S1066362220010178

6. A.A. Lizin, S.V. Tomilin, O.E. Gnevashov, A.N. Lukinykh, A.I. Orlova, "Orthophosphates of langbeinite structure for immobilization of alkali metal cations of salt wastes from pyrochemical processes," Radiochemistry, vol. 54, no. 6, pp. 542-548, 2012. http://dx.doi.org/10.1134/S1066362212060057

7. P.P. Poluektov, O.V. Schmidt, V.A. Kascheev, M.I. Ojovan, "Modelling aqueous corrosion of nuclear waste phosphate glass," J. Nucl. Mater., vol. 484, pp. 357-366, Feb. 2017.

https://doi.org/10.1016/j.jnucmat.2016.10.033

8. J. Choi, W. Um, S. Choung, "Development of iron phosphate ceramic waste form to immobilize radioactive waste solution," J. Nucl. Mater., vol. 452, no. 1-3, pp. 16-23, Sep. 2014.

https://doi.org/10.1016/j.jnucmat.2014.04.033

9. Kohobhange S.P. Karunadasa, C.H. Manoratne, H.M.T.G.A. Pitawala, R.M.G. Rajapakse "Thermal decomposition of calcium carbonate (calcite polymorph) as examined by in-situ high-temperature X-ray powder diffraction," J. Phys. Chem. Solids, vol. 134, pp. 21-28, Nov. 2019.

https://doi.org/10.1016/j.jpcs.2019.05.023

10. E.R. Vance, J. Davis, K. Olufson, I. Chironi, I. Karatchevtseva, I. Farnan, "Candidate waste forms for immobilisation of waste chloride salt from pyroprocessing of spent nuclear fuel," J. Nucl. Mater., vol. 420, no. 1-3, pp. 396-404, Jan. 2012.

https://doi.org/10.1016/j.jnucmat.2011.09.020

11. A.S. Wagh, Chemically Bonded Phosphate Ceramics. Twenty-First Century Materials with Diverse Applications, Eds., 2nd ed., Amsterdam, The Netherlands: Elsevier, 2016, pp. 1-422.

https://doi.org/10.1016/C2014-0-02562-2

12. S.E. Vinokurov, Y.M. Kulyako, O.M. Slyunchev, S.I. Rovny, B.F. Myasoedov, "Low-temperature immobilization of actinides and other components of high-level waste in magnesium potassium phosphate matrices," J. Nucl. Mater., vol. 385, no. 1, pp. 189-192, Mar. 2009.

https://doi.org/10.1016/i.jnucmat.2008.09.053

13. S.E. Vinokurov, S.A. Kulikova, V.V. Krupskaya, E.A. Tyupina, "Effect of characteristics of magnesium oxide powder on composition and strength of magnesium potassium phosphate compound for solidifying radioactive waste," Russ. J. Appl. Chem., vol. 92, no. 4, pp. 490-497, 2019. https://doi.org/10.1134/S1070427219040049

14. S.E. Vinokurov, S.A. Kulikova, V.V. Krupskaya, B.F. Myasoedov, "Magnesium potassium phosphate compound for radioactive waste immobilization: phase composition, structure, and physicochemical and hydrolytic durability," Radiochemistry, vol. 6o, no. 1, pp. 70-78, 2018.

https://doi.org/10.1134/S1066362218010125

15. S.E. Vinokurov, S.A. Kulikova, V.V. Krupskaya, S.S. Danilov, I.N. Gromyak, B.F. Myasoedov, "Investigation of the leaching behavior of components of the magnesium potassium phosphate matrix after high salt radioactive waste immobilization," J. Radioanal. Nucl. Chem., vol. 315, pp. 481-486, 2018. https://doi.org/10.1007/s10967-018-5698-3

16. S.E. Vinokurov, S.A. Kulikova, B.F. Myasoedov, "Magnesium potassium phosphate compound for immobilization of radioactive waste containing actinide and rare earth elements," Materials, vol. 11, no. 6, 976, Jun. 2018. https://doi.org/10.3390/ma11060976

17. S.E. Vinokurov, S.A. Kulikova, B.F. Myasoedov, "Solidification of high level waste using magnesium potassium phosphate compound," Nucl. Eng. Technol., vol. 51, no.3, pp. 755-760, Jun. 2019. https://doi.org/10.1016/j.net.2018.12.009

18. V.A. Shkuropatenko, "High level wastes immobilization in ceramic and hydrated phosphate matrix," East Eur. J. Phys., vol. 3, no. 1, pp. 49-6o, 2016. https://doi.org/10.26565/2312-4334-2016-1-0.5

19. L. Zhenyua, W. Hongtao, H. Yang, Ya. Tao L. Zhongyuan, L. Shuzhen, Zh. Haibin, "Rapid solidification of highly loaded high-level liquid wastes with magnesium phosphate cement," Ceram. Int., vol. 45, no.4, pp. 5050-5057, Mar. 2019. https://doi.org/10.1016/j.ceramint.2018.11.206

20. W.C. Lepry, B.J. Riley, J.V. Crum, C.P. Rodriguez, D.A. Pierce, "Solution-based approaches for making high-density sodalite waste forms to immobilize spent electrochemical salts," J. Nucl. Mater., vol. 442, no. 1-3, pp. 350-359, Nov. 2013.

https://doi.org/10.1016/j.jnucmat.2013.08

21. S.A. Kulikova, S.E. Vinokurov, "The influence of zeolite (Sokyrnytsya deposit) on the physical and chemical resistance of a magnesium potassium phosphate compound for the immobilization of high-level waste," Molecules, vol. 24, no. 19, 3421, Sep. 2019. https://doi.org/10.3390/molecules24193421

22. Федеральные нормы и правила в области использования атомной энергии "Сбор, переработка, хранение и кондиционирование жидких радиоактивных отходов. Требования безопасности," НП-о19-15, Ростехнадзор, Москва, Россия, стр. 1-22, 2015. (Federal Norms and Rules in the Field of Atomic Energy Use. In "Collection, Processing, Storage and Conditioning of Liquid Radioactive Waste. Safety Requirements," NP-019-15, Rostekhnadzor, Moscow, Russia, 2015, pp. 1-22.) Retrieved from:

https://www.secnrs.ru/en/science/development/norm d/

Retrieved on: Oct. 10, 2020

23. Отходы радиоактивные. Определение химической устойчивости отвержденных высокоактивных отходов методом длительного выщелачивания, ГОСТ Р 52126-2003, Стандартинформ, Москва, Россия, 2003. стр. 1-8. (Radioactive Waste. Long Time Leach Testing of Solidified Radioactive Waste Forms, GOST R 52126-2003, Standardinform, Moscow, Russia, 2003, pp. 1-8.)

Retrieved from: https://www.russiangost.com/p-69117-gost-r-521262003.aspx

Retrieved on: Oct. 10, 2020

24. Standard Test Methods for Determining Chemical Durability of Nuclear, Hazardous, and Mixed Waste Glasses and Multiphase Glass Ceramics: The Product Consistency Test (PCT), ASTM C1285-14, ASTM International, West Conshohocken, PA, 2014.

Retrieved from:

https://www.astm.org/Standards/C1285.htm Retrieved on: Oct. 10, 2020

25. S. Graeser, W. Postl, H.-P. Bojar, P. Berlepsch, T. Armbruster, T. Raber, K. Ettinger, F. Walter, "Struvite-(K), $\mathrm{KMgPO}_{4} \cdot 6 \mathrm{H}_{2} \mathrm{O}$, the potassium equivalent of struvite - new mineral," Eur. J. Mineralogy., vol. 20, pp. 629-633, May 2008. https://doi.org/10.1127/0935-1221/2008/0020-1810

26. K. Kaboosi, Kh. Emami, "Interaction of treated industrial wastewater and zeolite on compressive 
S. Vinokurov et al., Magnesium potassium phosphate matrix..., RAD Conf. Proc., vol. 4, 2020, 11-17

strength of plain concrete in different cement contents and curing ages," Case Studies in Construction Materials, vol. 11, eoo308, Dec. 2019. https://doi.org/10.1016/j.cscm.2019.e00308

27. F. Giacobbo, M. Da Ros, E. Macerata, M. Mariani, M. Giola, G. De Angelis, M. Capone, C. Fedeli, "An experimental study on Sodalite and SAP matrices for immobilization of spent chloride salt waste," $J$. Nucl. Mater., vol. 499, pp. 512-527, Feb. 2018.

https://doi.org/10.1016/j.jnucmat.2017.11.051 